ON THE RECORD

(CThere are a lot of testicles around."

Chris Barratt of Birmingham Women's Hospital explains why stem cells from testicles could be a useful alternative to those from human embryos.

\section{'(I haven't done any conquering, per se."}

Tom Robinson, an accounting professor, considers his newly identified genetic link to Genghis Khan.

\section{cswabbing butts is not my highest priority, but it's a national emergency kind of thing.")}

Biologist Rick Lanctot bites the bullet and samples shorebirds in Alaska for the H5N1 flu virus.

Sources: The Guardian, Miami Herald, Reuters

\section{SCORECARD}

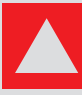
Sporting ants Scientists fiddle with ants' pheromones to whip up team rivalries in the world's tiniest football match: the Ant World Cup.

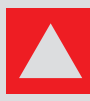
Horse whispering An acoustics scientist finds that horse whinnies are far more complex than originally believed.

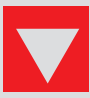
Young footballers Kids playing football in new boots can end up with toxic shock syndrome from blisters, doctors report.

\section{NUMBER CRUNCH}

Have jet fuel, will travel. Inventor Brian Walker is building a massive, cross-bow-style rocket launcher in a bid to fire himself 32 kilometres in to the air this autumn.

\section{6,000 newtons is the} thrust Walker hopes his homemade rocket will achieve.

7 metres is the length of the carbon-fibre 'bow' Walker will use to launch the rocket.

\section{$\$ 15,000$ is the cost of}

Walker's safety gear: a surplus Russian space suit.

Source: Wired

\title{
Cash for papers: putting a premium on publication
}

\section{TOKYO}

Financial rewards for publishing high-profile papers are spreading. Starting later this month, South Korean researchers will receive US $\$ 3,000$ from the government when they publish in elite journals. And that's a pittance compared with China, where some scientists can rake in more than ten times that amount.

As institutions and countries strive for international recognition, some are hoping that publication bonuses will help. But critics fear that this strategy could lead to a dangerous fixation on a few indicators of scientific success.

The Korean initiative, funded by the Ministry of Science and Technology, will award 3 million won (US\$3,000) to the first and the corresponding author on papers in key journals. "The plan is part of efforts to raise the morale of scientists who boost development in the country's science and technology sector," says Young Nam Lim, deputy director at the ministry's department of basic science policy. A ten-member committee composed of ministry officials and researchers will choose the relevant journals. They are likely to include Nature, Science and Cell among others, Lim says.

Similar practices are already in place elsewhere. In Pakistan, under a system introduced by the science ministry in 2002, researchers can receive $\$ 1,000$ to $\$ 20,000$, based mainly on the cumulative one-year impact factor of their publications. Half is given as a research grant and the rest for personal use.

In China, bonuses are left up to the individual institution. China Agricultural University in Beijing, for example, will pay up to $\$ 50,000$ for high-impact papers, says its president Zhang-liang Chen. "This is not a big deal for great papers," he says.

The Chinese Academy of Sciences' Institute of Biophysics in Beijing has a scale tuned to impact factors. Authors published in journals with an impact factor between 3 and 5 receive 2,000 yuan $(\$ 250)$ per point, while a factor over 10 earns 7,000 yuan (\$875) per point. A paper in Nature, Science or Cell earns 250,000 yuan $(\$ 31,000)$. The institute has had several such papers published over the past few years.

Advocates of the bonus schemes say that the incentives compensate for the low academic wages in the countries concerned. A bonus of
$\$ 1,000$, for instance, could be three times the monthly salary of a Pakistani university lecturer. Thanks partly to the incentives, the output of papers has increased dramatically, says Atta-ur-Rahman, chairman of the Pakistan government's higher education commission, who helped introduce the reward system.

But critics charge that more papers aren't necessarily better. "The bonus plan has had a devastating effect," says Pervez Hoodbhoy, a physicist at Quaid-i-Azam University in Islamabad. "University researchers are rushing to publish by hook or by crook, and scientific and academic ethics are ignored in this haste." He suspects that many papers with little significance are churned out, and says that bonuses could be adding to the problems of plagiarism and faked data that he has seen and heard.

Others feel that the bonus system belittles their work. "Good papers are the product of sweat, joy and sorrow," says Sunyoung Kim, a biologist at South Korea's Seoul National University. "If this is calculated to be 3 million won, I feel insulted."

Yuan Tseh Lee, a Nobel prize-winning chemist, agrees. "There is too much pressure on scientists to get recognition in China," says Lee, who is president of Taiwan's Academia Sinica. "If you just aim for fame and money, you will make yourself and your students miserable."

Partly because of such concerns, the Shanghai Institute of Biological Sciences cancelled its bonus program in 2003. But Chen argues that at the moment bonuses are necessary, especially in China where a socialist system has made it difficult to reward hard work. "It's a necessary stage," he says. "In ten years I'm sure the situation will be different."

Peter Cotgreave, director of the Londonbased lobby group the Campaign for Science and Engineering in the UK, says reward systems have some merit, in part because the people effectively judging the award - anonymous peer reviewers - are independent of the award. Deserving researchers might miss out, he says, when, for example, high-quality papers are rejected by top journals. But he doubts that poor work would be rewarded, as researchers "only win if they are good enough to get into Nature or Science". Ichiko Fuyuno and David Cyranoski 